\title{
Thematic implications and representativeness in Wuthering Heights (1848): Dialect as a social reality
}

Fatiha Belmerabet *, University of Tlemcen, Tlemcen, Algeria

\section{Suggested Citation:}

Belmerabetn, F. (2021). Thematic implications and representativeness in Wuthering Heights (1848): Dialect as a social reality. International Journal of New Trends in Social Sciences. 5(1), 16-27.

https://doi.org/10.18844/ijntss.v5i1.5499

Received February 22, 2021; revised March 14, 2021; accepted May 23, 2021.

Selection and peer review under responsibility of Prof. Dr. Huseyin Uzunboylu, Higher Education Planning, Supervision, Accreditation and Coordination Board, Cyprus.

(C)2021 Birlesik Dunya Yenilik Arastirma ve Yayincilik Merkezi. All rights reserved.

\begin{abstract}
Since language is a brainwork of speakers who live in social and physical environments, researchers are obliged to think about the alliance between the vocabularies' meaning in dictionaries and their significance in social use. And because the novel is a fictional piece of writing which is primarily inspired by real life and reflects realities. In Wuthering Heights, Emily Bronte strives to interfere in her characters' thought and considers their social class, culture and experience; she acts as a writer, the speaker and the reader as well. These authorial qualities gave birth to a text combined of two language varieties, the Standard English and the Yorkshire dialect which are tightly interwoven without distorting the unity and the arrangement of the story plot. This paper looks to cover the different social inclinations of E. Bronte's depiction of dialect in addition to some critical resonances of such representation.
\end{abstract}

Keywords: Wuthering Heights, dialect representativeness, social reality, thematic implications, language.

* ADDRESS FOR CORRESPONDENCE: Fatiha Belmerabet, University of Tlemcen, Tlemcen Algeria.

E-mail address: fatiha.belmerabet@univ-tlemcen.dz 


\section{Introduction}

When looking at its linguistic composition, Wuthering Heights represents a diglossic situation in which the Yorkshire dialect is put in sharp contrast with Standard English. E. Bronte deviates from the standard variety of English occasionally and mainly when her dialect-speaking characters converse yet, the long descriptive and narrative paragraphs and the conversations of the standard-speaking characters are written in Standard English. This alteration is noted by Hymes (1971) as being a situation in which a monolingual individual, in this case, the author, changes his style from one variety of the same language to another creating a diglossic context. Here, the author tries to convey a social meaning through dialect use to differentiate between her characters' class, literacy and culture. This type of differentiation can be achieved and conveyed only through a comparison of usage between dialect and Standard English in the novel.

Solano-Flores (2006, p. 2,360) states: 'dialect is frequently used to refer to the language used by people from a particular geographic or social group or to mean a substandard variety of a language'. Also, Haugen (1966, pp. 924-5) posits: 'the dialect is often thought of as standing outside the language.... As a social norm, then, a dialect is a language that is excluded from polite society'. Yet, the dialect in Wuthering Heights promotes more themes that are peculiar to its users. It is used as a tool to empower the character Joseph and also to point out the different casts in Victorian society. The author also longs to improve the knowledge of the audience about the real environment of Yorkshire and attempts to change the perception which former literary representations had implanted in the minds of people outside the area. Dialect, this time, is used neither to convey a comic sphere nor to embellish the text and not as the common tool to support local colour views in the novel. It is employed as a basic portion of the novel which achieves serious thematic objectives. It renders the old social, religious and cultural ways which appertain to a specific era of the English society in remote and unfamiliar areas most of which are either ignored or misconceived. Dialect correctness denotes $\mathrm{E}$. Bronte's influence by her motherland and her origins that help her to portray Joseph speaking dialect in long paragraphs on more than 14 occasions without switching to Standard English. Her choice of language changes depending on a set of circumstances such as the literacy level and the social class of the character to convey meanings that are suitable to the context in which it is used. She retains both the linguistic accuracy and the aesthetic artistry of her depiction. Moreover, the remote dialectal vocabulary items employed in the novel afford the text connotations which are beyond the reach of Standard English.

\section{Joseph's dialect: An analogy to Yorkshire social reality}

Wuthering Heights is, surely, a telling novel which is mostly accomplished by its setting in the Yorkshire fields and by the portrayal of the rustic community that is done in a realistic manner. Since language is the unique medium between the audience and the fictional world, E. Bronte picks out a linguistic style most appropriate to explain and express her fictional subject and thoughts viably and realistically. Furthermore, as the fictional world's verbalism is decided by means of the spoken words, the combination of dialectal speech and Standard English in the novel provides a holistic interpretation of characters' status, themes, cultural belonging and the plot's structure in an aesthetic way.

One of the most important features that define the power of this novel and contribute to the integrity of its location is the use of the Yorkshire dialect through the mouth of some characters in a relative manner. Yet, the old servant at Wuthering Heights' estate 'Joseph' entirely converses in dialect. He is portrayed as a religious and faithful servant. Nelly Dean describes him as: 'the wearisome, self-righteous Pharisee that ever ransacked a Bible to rake the promises to himself and fling the curses on his neighbours' (Bronte, 1849, p. 43). From this description, it is noticed that this character carries some personality treats that show his self-centredness, rudeness and extremism. Consequently, Joseph is a puzzling character and he is observed from different perspectives. From one 
perspective, he is constantly bad-tempered, very rough, even rude and stingy sometimes. From another stance, he is an old man who is constantly honest, steadfast and obedient to his masters and a person who firmly carries the traditional convention of his community.

Joseph's utilization of dialect mirrors the harshness of Wuthering Heights' story and the environment in which it is located. The old man speaks an old dialect (Yorkshire dialect based on the Haworth dialect) and lives in an old large estate. The house is tenable, however, not adequate as it is constantly caught by storms and the violent climate of the moors yet shows a great resistance and solidity. Similarly, Joseph's dialect remains constant because it is clearly displayed and authentically depicted. It is difficult to comprehend and it is always underestimated by the higher classes which cast dialect-speaking people in an inferior stratum. Since dialect is already predestined to define a class and to set a character in a particular region as Chapman (2017) puts it, Joseph's locution denotes his locality and his social status as well. Despite the fact that his vernacular sounds very unpleasant, rustic, reflective of his mood and difficult for a non-dialect speaking reader, there is a charm in it. Moreover, a great part of reality lies in, much the same as the real Yorkshire fields are said to be harsh, however, lovely (Gorlach, 1999).

Eventually, among the many features it proposes, dialect is an indicator of illiteracy and crudeness and 'can connote various degrees of inferiority, with that connotation of inferiority carried over to those who speak a dialect' (Wardhaugh, 2002, p. 28), especially, because it is utilized solely by Joseph. In any case, Joseph and his dialect oppose everyone in Wuthering Heights. He approaches and disagrees with all the characters of the novel and is in conflict with them. Contrary to other characters, his speech shows no development or change from the beginning until the end. In opposition to, for example, Heathcliff's speech which changes and develops from 'some gibberish that nobody could understand' (Bronte, 1849, p. 23) in the beginning of the story to Standard English that is more cultivated and classier by the mid and the end of the novel.

This variation in Heathcliff's speech which does not appear in Joseph's is purposely done by the author to leave Joseph at the margin of the novel's fictional world just as the Yorkshire area is left remote and unknown by the people outside the region also because Joseph's role in the story has little influence in the plot advancement. Emily Bronte just conveys Joseph's position of a servant just as in the real world, to approach the social orders through her work in a realistic manner without romanticizing Joseph's status.

This approach is fulfilled through the means of linguistic representation. Joseph's discourse is not continuously simple to comprehend, but it is a fundamental portion of the novel since it accentuates the significance of social boundaries in the Victorian era. Moreover, Joseph's discourse acts as a considerable motor in the advancement of the general mood of the story through the characters' reactions to it (Ferguson, 1998). According to Waddington-Feather (2003), Bronte's utilization of the Yorkshire tongue fortifies the readers' awareness of the social zone in which the novel is set and helps it to appear more realistic. Therefore, Joseph is a character who gives a realistic tint to the story and represents the people of the Yorkshire area and their language features.

\section{Joseph's dialect thematic implications in Wuthering Heights}

After the rise of Standard English as the language of prestige and literature, Yorkshire dialects were viewed as the speech of the ignorant and uninstructed people living in rustic areas of Britain. Thereby, its manifestation in the literature was seen in literary works in which writers failed in their literary objectives in Standard English and escaped to dialect to convey a message or a specific image. However, the dialect in Wuthering Heights displays a very important role in revealing significant themes which contribute to the general atmosphere and the mood prevailing in the story. Bronte's incorporation of Yorkshire dialect and the accuracy in portraying Joseph's speech grant the novel its literariness, acknowledgement and even respect in the nineteenth century because it reflects the Victorian everyday life and produces an adventure of the provincial life. The following subsections set 
different themes which the author tries to uncover through the character Joseph and his Yorkshire locution.

\subsection{Religious implications of Joseph's utterance}

On several occasions, Joseph in the novel, speaks about religion and plays the role of the preacher. He feels a responsibility towards his masters and wants to guide them to the right path according to his perception. His speech consists of religiously oriented images and expressions. Lockwood narrates one of the occasions mentioned in Catherine's diary in which Joseph is telling his master about Cathy and Heathcliff's deceptive adventure in the moors:

'Maister Hindley!' shouted our chaplain. 'Maister, coom hither! Miss Cathy's riven th' back off 'Th' Helmet o' Salvation,' un' Heathcliff's pawsed his fit into t' first part o' ' $T$ ' Brooad Way to Destruction!' It's fair flaysome that ye let 'em go on this gait. Each! th' owd man wad ha' laced 'em properly - but he's goan!' (Bronte, 1849, p. 23).

In this heavy dialectal passage, Joseph judges them and shows his worries about their faith. Even Catherine represents Joseph as being their chaplain as if he is a minister in a church and not a servant in their estate.

The reader feels here that Joseph holds the sceptre of salvation and damnation as well. Moreover, Joseph thinks that he is responsible to spare them the: 'broad road to destruction' (Stuchiner, 2013, p. 191). He charges the acts of the members of the gentry on each occasion; he scolds them and behaves like a missionary of God. Joseph's point of view regarding the other characters' behaviours reflects the biased and misleading general opinion of the nineteenth century's people of rural England regarding the religious faith which is referred to as 'religious terrorism' that is commonly accompanied by the harsh treatment of the Christian believers and promotes 'humility and submission' (Stuchiner, 2013, p. 193).

Jane Hodson (2016, p. 32) posits that the use of dialect in Joseph's locution conveys 'the harsh but more conventional morality of Joseph' however it is 'made strange' by his 'nearly incomprehensible language'. This opinion shows the difficulty of Joseph's speech that is linked to his religious stance and the manner he reveals it since his rudeness is often transmitted by his words. This is done on purpose by the author to transmit and denunciate harsh, strange convictions.

Joseph is unquestionably right as he would like to think that the people in Wuthering Heights' estate are in moral danger and he prays for God's salvation each time he encounters behaviour which does not fit his religious opinion 'Oh wicked, wicked! May the Lord deliver us from evil!' (Bronte, 1849, p. 16). However, his ways to convey this presumed righteous opinion are misleading and violent. He coercively attempts to instruct the members of Wuthering Heights using his own religious conventions. Catherine narrates his speech after her father's death:

'T'maister nobbut just buried, and Sabbath not oe'red, und t'sound o't' gospel still I'yer lugs, and ye darr be laiking! Shame on ye! Sit ye down, ill childer! There's good books eneugh if ye'll read ',em; sit ye down, and think 0' yer souls! (Bronte, 1849, p. 22).

This passage is full of dialectal vocabulary items that are linguistically heavy and emotionally charged with scaffoldings. Joseph endeavours to protect himself and the other members of the Earnshaw family, particularly Catherine, from Heathcliff's devilish behaviour since Joseph perceives Heathcliff as a danger to her. Joseph's entire grittiness renders him safe from Heathcliff's malevolent profound impact. Moreover, Joseph's own crooked understanding of religion is more realistic from every angle of the nineteenth century's rehearses in the Yorkshire area. This understanding gives Joseph knowledge into Heathcliff's mind that is properly conveyed to the reader through unlimited attacks. 
Joseph's ceaseless references to Heathcliff's devilish spirit have a total impact all through the novel, adding to it a superstitious component that is Joseph's own. Joseph is portrayed as a highly superstitious character who sees Heathcliff's darker skin colour as an omen to the entire family.

When the structure of the novel is analysed, it is seen more closely how the novelist has utilized Joseph and his dialect to convey a religious vista. Joseph generally comes into the novel at those significant moments when Heathcliff requires delineation of a barbarous and brutal type. Joseph shadows Heathcliff like a demon or as an inferior soul with respect to a preeminent and hateful power. Through his closeness, Joseph provides a metaphor that makes Heathcliff's character more natural and dynamic.

\subsection{Violence and intensity in Joseph's speech}

The old Joseph is obviously, the principal agent of dialect in the novel. Furthermore, Emily Bronte's comprehension of this diabolic imposter together with his dialect, are sufficient to judge now that it took a lot of inventiveness, and a huge boldness, for the author to make a character talking such a restricted dialect in a novel of this eminence. She does not deviate from her realistic strategy of depiction and never lends Joseph some pseudo, stereotyped Northern dialect or standard like other writers formerly did for dialect-speaking characters.

However, Bronte makes Joseph a loud-voiced, Haworth dialect speaker, utilizing words and terms which are expelled from Standard English. Instead of making Joseph merely unintelligible and disturbing, Bronte makes him one of the indispensable minor characters who play a telling part in making the hugely serious and violent climate that pervades the entire novel. As far as harshness is concerned, Petyt notes that: "one probably crucial feature, the "West Yorkshire tone of voice", variously described as "harsh", "loud"' (Petyt, 1985, p. 241). This view is displayed by Bronte through Joseph's speech which reflects her realistic exemplification of the Yorkshire man.

Moreover, Joseph's violent character excludes no one - even Nelly the housekeeper because; Bronte always defends Catherine against-Joseph's unemotional behaviour. Joseph speaks plainly against the coming of Linton to the estate; he spares no occasion to sneak his nose in their matters. In one of the occasions, Joseph devilishly thrusts an argument against three characters, Heathcliff, Catherine, and Nelly as she narrates:

'If I war yah, maister, l'd just slam t' boards i' their faces all on 'em, gentle and simple! Never a day ut yah're off, but yon cat o' Linton comes sneaking hither; and Miss Nelly, shoo's a fine lass! shoo sits watching for ye i' t' kitchen; and as yah're in at one door, he's out at t'other; and, then, wer grand lady goes courting of her side! It's bonny behaviour, lurking amang $t^{\prime}$ fields, after twelve o' $\mathrm{t}^{\prime}$ night, wi' that fahl, flaysome divil of a gipsy, Heathcliff! They think I'M blind; but I'm noan: nowt ut t' soart! - I seed young Linton boath coming and going, and I seed $\mathrm{YAH}^{\prime}$ (Bronte, 1849, p. 92).

In this loaded dialectal excerpt, Joseph is urging his master, Hindley, to punish Catherine since she is looking for Heathcliff after he departed from the estate. Similarly, Joseph is accusing Nelly of being involved in the bad behaviour of her mistress. He leaves no incident without launching his harsh criticism and referring to his misleading vista. The old servant ironically criticized Catherine and Nelly's behaviour when Hindley is absent as he says: 'It's bonny behaviour, lurking amang $t$ ' fields, after twelve o' t' night'. Likewise, he is launching a set of bad qualifying adjectives towards Heathcliff: 'fahl, flaysome divil of a gipsy' and showing his careful attention to the conduct of the other characters: 'They think I'M blind; but I'm noan: nowt ut t' soart!'. Although Joseph does not have the authority to punish them, since he is a mere servant, he looks for someone who can do it instead. Therefore, Joseph is portrayed as a manipulative man who endeavours to practice his violence on the other characters. 


\section{Tragic-comic representativeness in Joseph's utterance}

It is additionally noteworthy that Joseph gives the few occurrences of diversion which break into the novel. Like a humourist in incredible tragic scenes, his image of humour is terrible and gloomy. At the same time, it keeps the appalling viciousness being played out about him. When Joseph meets Nelly and narrates her novelties at Wuthering Heights, he speaks about Heathcliff who returns and his purpose to destroy Hindley Earnshaw by playing him at dice; meanwhile, he is restoring his passion with Catherine, who is married to Mrs. Edgar Linton. Joseph's depiction is funny and disastrous. Furthermore, it is peculiar and perfect in terms of the facts it provides and the impact Heathcliff's return is playing on the Earnshaws and Lintons together. He says:

'we's hae a crahner's 'quest enah, at ahr folks'. One on 'em 's a'most getten his finger cut off wi' hauding t' other fro' stickin' hisseln loike a cawlf. That's maister, yeah knaw, 'at 's soa up o' going tuh $t^{\prime}$ grand 'sizes. He's noan feared $o^{\prime} t^{\prime}$ ' bench o' judges, norther Paul, nur Peter, nur John, nur Matthew, nor noan on 'em, not he! He fair likes - he langs to set his brazened face agean 'em! And yon bonny lad Heathcliff, yah mind, he's a rare 'un' (Bronte, 1849, p. 109).

He continues his account about Heathcliff:

'He can girn a laugh as well's onybody at a raight divil's jest. Does he niver say nowt of his fine living amang us, when he goes to $t^{\prime}$ Grange? This is $t^{\prime}$ way on' $t$ :- up at sun-down: dice, brandy, cloised shutters, und can'le-light till next day at noon: then, $\mathrm{t}^{\prime}$ fooil gangs banning und raving to his cham'er, makking dacent fowks dig thur fingers i' thur lugs fur varry shaume; un' the knave, why he can caint his brass, un' ate, un' sleep, un' off to his neighbour's to gossip wi' $t^{\prime}$ wife. I' course, he tells Dame Catherine how her fathur's goold runs into his pocket, and her fathur's son gallops down $\mathrm{t}^{\prime}$ broad road, while he flees afore to oppen t' pikes!' (Bronte, 1849, p. 110).

This quote comprises considerable dialectal linguistic details which show that Joseph is distant from everyone else in having the non-standardness of discourse. His speech is set apart in a very distinguished way. It is substantially further from Standard English even when compared to other characters' speech; those having the same social class like 'Nelly' and 'Zillah' and also further from those Yorkshire dialect-speakers like 'Hareton' who is illiterate. Joseph is giving a minute description of events using images and qualifiers about people and their behaviours. His narration sways between serious and tragic details; it is funny, sarcastic, and enfolds tragic hints. He does not forget to refer to religion, every time, he converses about a member he considers unreligious. The way Joseph speaks and reacts to the other characters displays the common points of view of his community. Themes like religion and sarcastic denunciations of strange behaviours are representative of the social reality of Yorkshire especially, for lower-class people.

The violence and intensity of Joseph's speech have been shown since the beginning of the story. He makes the intensely threatening environment that forecasts all the savagery which happens later. He receives Lockwood in a very rude manner, the sort of welcome which is expected from Heathcliff's servant. He keeps up this antagonistic effect which stuns the civilized southerner. His gloomy refusal to assist him when this misguided voyager looks for induction to Wuthering Heights reveals his rudeness and his inhospitality. The next discussion between Joseph and Lockwood displays his rude welcome and his sarcastic mockery which he plainly shows to this new lodger in the estate. In the following excerpt Lockwood is narrating Joseph's reception at Wuthering Height:

'What are ye for?' he shouted. 'T' maister's down i' t' fowld. Go round by th' end o' $t$ ' laith, if ye went to spake to him'.

'Is there nobody inside to open the door?' I hallooed, responsively.

'There's nobbut t' missis; and shoo'll not oppen 't an ye mak' yer flaysome dins till neeght'. 
'Why? Cannot you tell her whom I am, eh, Joseph?'

'Nor-ne me! I'll hae no hend wi't', muttered the head, vanishing'(Bronte, 1849, p. 10).

After this inhospitality which is ostensibly expressed, at last, Joseph imposes on the reader the horrible impression of Wuthering Heights and the people who are imprisoned there which he would later conclude by following the events at night. He sets his dogs on Lockwood as Lockwood seizes Joseph's lamp to make his own track to the estate.

During his resting time, Lockwood has a loathsome bad dream of Joseph and his companions beating him in the church room. This nightmare shows that the hostile nature of Joseph haunts even the dreams of Lockwood and reveals that even other people share the same characteristics as Joseph.

Joseph's heavy dialectal speech is best associated with tragic-comic scenes when Isabella Linton is first acquainted with Wuthering Heights following her decision to marry Heathcliff. What she affectionately thought would be a perfect marriage is broken from the first time she comes into the house. She meets Hareton Earnshaw who intimidates her to set his bulldog. She withdraws to the kitchen where Joseph is making the evening's porridge. Taking on the position of the house lady and being hungry herself, she ousts Joseph from the kitchen and wants to cook. The following quote is narrated by Isabella herself in which she portrays Joseph's response to her order comically and mockingly:

'Gooid Lord!' he muttered, sitting down, and stroking his ribbed stockings from the knee to the ankle. 'If there's to be fresh ortherings - just when I getten used to two maisters, if I mun hev' a MISTRESS set o'er my heead, it's like time to be flitting. I niver DID think to see $\mathrm{t}^{\prime}$ day that I mud lave th' owld place - but I doubt it's nigh at hand!' (Bronte, 1849, p. 148).

Humour, violence and tragic scenes are shown in the language of Joseph for he shows no pity and no understanding to Isabella. He refuses to have Isabella as a Mistress at Wuthering Heights. His language and tone reflect the traditional point of view of nineteenth century's Britain which saw women as inferior creatures even for the lower classes. Thus, patriarchy and gendered censorship are also mirrored in the dialectal speech of this character. Tragic scenes continue to bitter Isabella's feelings, not only by words but also by the behaviour of Hareton and Joseph whose disgusting manners are bothering her. In another scene, Isabella requests to be guided to another room where she can eat her supper without anyone else. In her refined classy way, she continues narrating her first horrible evening at Wuthering Heights and Joseph's comic and unthoughtful response to her request:

'I shall have my supper in another room', I said. 'Have you no place you call a parlour?'

'PARLOUR!' he echoed, sneeringly, 'PARLOUR! Nay, we've noa PARLOURS. If yah dunnut loike wer company, there's maister's; un' if yah dunnut loike maister, there's us' (Bronte, 1849, pp. 149-150).

Joseph's rising voice and grim humour complicated more the situation of Isabella who is embarrassed by the changing climate of her life, from the classy Grange where the Lintons reside to the gloomy Wuthering Heights, the empty estate inhabited by disgusting and rude people Hareton, Joseph and Heathcliff. Joseph's playable words and rude tone complicate more the situation of Isabella who cannot bear such behaviour.

The servant continues his mockery of Isabella's request for a room. He guides her to a 'kind of lumber-hole smelling strong of malt and grain' as she describes in her letter. In their way to it, he carries on his sarcasm:

'Here's a rahm', he said, at last, flinging back a cranky board on hinges. 'It's weel eneugh to ate a few porridge in. There's a pack o' corn i' $\mathrm{t}^{\prime}$ corner, thear, meeterly clane; if ye're feared o' muckying yer grand silk cloes, spread yer hankerchir o' t' top on't (Bronte, 1849, p. 150). 
Joseph's speech shows an outrageous underestimation of the lady who is supposed to be Heathcliff's wife and the mistress of the estate. His humorous way causes desperation to Isabella who starts to hate the place and regrets her elopement from the Grange. Consequently, Isabella thinks of her destiny which is linked to this hellish estate. Eventually, the latter asked for the bedroom to sleep and another time, Joseph intervenes and viciously responds:

'BED-RUME!' he repeated, in a tone of mockery. 'Yah's see all t' BED-RUMES thear is - yon's mine'.

'Oh! it's Maister HATHECLIFF'S ye're wanting?' cried he, as if making a new discovery. 'Couldn't ye ha' said soa, at onst? un' then, I mud ha' telled ye, baht all this wark, that that's just one ye cannut see - he allas keeps it locked, un' nob'dy iver mells on't but hisseln' (Bronte, 1849, p. 150).

In all the aforementioned quotes, Joseph is again being utilized as an agent to elevate the unfortunate circumstances in which Isabella is entrapped. His earthly and heartless character aggravates the sudden hopelessness and wretchedness of Isabella. Joseph's social rudeness precedes the physical and mental agony which Heathcliff brings upon her later, as he deliberately approaches the devastation of the Lintons and the Earnshaws to fulfill his horrible revenge.

Much a similar treatment is distributed to Isabella's child, Linton Heathcliff when he is asserted by his father after Isabella's demise. Again, it is Joseph who supplements his Lord's enmity with his particular image of antagonistic attitude. It is over the porridge bowl that Joseph expresses his hatred as Linton declines to eat the porridge which the servant has prepared. Although Heathcliff compels his servants to respect him, Joseph voices his disapproval of the young Linton's declination to eat and murmurs as Nelly narrates:

'Cannot ate it?' repeated he, peering in Linton's face, and subduing his voice to a whisper, for fear of being overheard. 'But Maister Hareton nivir ate nowght else, when he wer a little 'un; and what wer gooid enough for him's gooid enough for ye, l's rayther think!' (Bronte, 1849, p. 222).

Joseph continues his contend by comparing the young Linton's behaviour to his mother's. Then, he says: 'Wah!' answered Joseph, 'yon dainty chap says he cannut ate 'em. But I guess it's raight! His mother wer just soa - we wer a'most too mucky to sow t' corn for makking her breead' (Bronte, 1849, p. 222). These words raise Heathcliff's anger and orders Joseph not to mention Isabella's name before him. Joseph's attempts to influence Heathcliff fail this time and his opinion about the other characters becomes less significant.

\section{Joseph's speech as a representative dialect}

Steadily, the abhorrent impact of the old Joseph decreases with that of his Lord Heathcliff, and his character is lessened to just a comic one. The more powerful the love of the young Cathy Linton and Hareton Earnshaw grows up, the more jokester and less a malevolent soul Joseph is. He is horrified and astonished at seeing the two youngsters' love becoming strong. One day on his arrival from the dairy cattle store, he voices his objection in an unquestionable manner. Joseph has respected the religious and social principles all his life; he is loyal to his masters and it does not appear to be reasonable that, by the end of the day, the total of what he has are a Bible and a heap of 'dirty banknotes' which he has to give back to the owner. In one of the scenes, he appears ordering Hareton to give back the bank-note to Heathcliff: 'Tak' these in to t' maister, lad', he said, 'and bide there. Aw's gang up to my own rahm. This hoile's neither mensful nor seemly for us: we mun side out and seearch another' (Bronte, 1849, p. 333). Here, he shows that the estate is like a hole that is neither appropriate to live in nor good for him.

At last, Joseph is seen again in another preeminent comic episode when Cathy and Hareton have removed the bushes which belong to Joseph's yard. Furiously and stunningly, Joseph goes to announce this deceitful incident to Heathcliff. Nelly describes his wordless mouth trembling and his jaws moving like those of a cow. He reports the event to Heathcliff in a very difficult dialect: 
'I mun hev' my wage, and I mun goa! I HED aimed to dee wheare I'd sarved fur sixty year; and I thowt I'd lug my books up into $\mathrm{t}^{\prime}$ garret, and all my bits o' stuff, and they sud hev' $\mathrm{t}^{\prime}$ kitchen to theirseln; for $t^{\prime}$ sake o' quietness. It wur hard to gie up my awn hearthstun, but I thowt I COULD do that! But nah, shoo's taan my garden fro' me, and by th' heart, maister, I cannot stand it! Yah may bend to th' yoak an ye will - I noan used to 't, and an old man doesn't sooin get used to new barthens. I'd rayther arn my bite an' my sup wi' a hammer in th' road!'( Bronte, 1849, p. 336).

Heathcliff interferes to stop Joseph's complaint and tells him that he will never interfere in an argument between him and Nelly. He declares to let him down even if she throws him in coal hole. Heathcliff's response shows his recklessness about Joseph's matters and struggles. However, all in vain, Joseph continues explaining again to his master that the quarrel is not between him and Nelly but Hareton.

Joseph accused the young Cathy of influencing Hareton and witching him with her unrefined manners and that he forgets all that the old servant has done for him. This incident harms Joseph deeply. The impact of the old man has gone and the removal of the bushes to be supplanted by flowers of more delighting quality are representatives of the vanishing impact of meanness in Wuthering Heights which is altered by the energy of goodness.

The novel comprises other instances of different occurrences of Yorkshire dialect altered by characters other than the old Joseph, for the most part by Hareton, the young man raised under Joseph and Heathcliff's influential mentality. Like Joseph, he converses in dialect, often described by Bronte as 'the frightful Yorkshire pronunciation' (Bronte, 1849, p. 234) to accentuate the violence and the fierceness which Heathcliff and Joseph had cultivated in him. E. Bronte has utilized his dialect with a specific affiliation, and it is clear that the more illuminated Hareton ends up plainly under the instruction of the young Catherine, the less he talks dialect and the further he distances himself from the bad impact of Joseph and Heathcliff.

The thematic implications of dialect in the framing of the climate of Wuthering Heights show the function of Joseph's speech to create a specific atmosphere for the story. In all the former quotes, E. Bronte endeavours to put plenty of linguistic particularities related to pronunciation and grammar in addition to the Yorkshire vocabulary items. The next section tries to discern some social attributes to show Bronte's effort to render dialect and Standard English and their functions in shaping the novel's fictional lines and plot.

\section{Dialect and standard English in Wuthering Heights as pointers of social reality}

Novelists have always been preoccupied with their characters' social class which is the rank of the social conditions they cover in their fictional societies that are inspired by real societies. The class is employed by authors to render distinct properties of these characters in the fictional world which is an artistic mirror of reality. This employment longs to spotlight the dissimilarities amongst characters of various classes. Language is often utilized to show these disparities at various levels. Among the most important ones: education, prestige, naivety, sophistication, and comedy are cited as examples.

\subsection{Social mobility as part of social reality}

In Wuthering Heights, the social class is displayed through the linguistic behaviour and the language variety that characters employ when conversing. For Joseph, the main dialect-speaking character, he uses dialect all the time with all the characters, either from a higher class or with his fellow servants. This reflects his static social position as the servant in the estate until the end. However, Heathcliff's social mobility is highlighted through the amelioration of his language from 'some gibberish', which makes Edgar Linton call him a 'gipsy' to the standard variety of English which is perceived by Nelly as 'a foreign tone'. His language changes as his social class does. When he becomes the master of Wuthering 
Heights, he tends to demonstrate his social levelling by speaking the language appropriate to the upper class. His domination is not at the level of wealth only, but also at the level of speech. Here, the standard variety is a marker of superiority and a pointer of the social integration of Heathcliff.

Catherine's language and manners as well change when she becomes the spouse of the master in Linton's Grange. This change is done intentionally by Catherine because; she works on her manners to become a 'lady'. She gives up her love to Heathcliff in search of a better social position and a good reputation in the Lintons view. Joseph, Heathcliff, and Catherine belong to the same speech community however, they interact in different ways. This is mainly because of their social status. Even though they use different varieties, they still maintain intelligibility. This level of understanding between them is approached because they share the same conventional concept of what is correct in language.

Education level is rendered through the absence of the Standard English variety for the characters Joseph, Hareton, and Zillah; these characters are either servants or uneducated people. The uneducated Hareton is brought up by Joseph whose speech is purely dialectal and by Heathcliff who pulls him down to the class of servants. Hareton's utterance is commented by Isabella as being 'a jargon' which is difficult to understand. Furthermore, he represents a confusing character for Lockwood who questions himself whether Hareton is a servant or a member of the gentility. After Heathcliff's demise, Hareton gets rid of the domination of Joseph and Heathcliff together; he starts reading to improve his utterance to a more refined language. This improvement is reached by the assistance of the young Cathy who urges him to read and instruct himself because he is no more a servant, but a member of the gentility.

As far as Nelly is concerned, she is a servant yet; she uses a refined language that is near to that of her masters. Lockwood argues: 'Excepting a few provincialisms of slight consequence, you have no marks of the manners that I am habituated to consider as peculiar to your class' (Bronte, 1849, p. 18). Lockwood finds her language close to his yet; these 'few provincialisms' are pointers of her origins and social class as a Yorkshire servant. She, responsively, argues that she acquires her standard variety from the books she reads at the Linton's library. Furthermore, Nelly's language is different from that of Joseph though they occupy the same position. Her language allows her to achieve successful communication with other characters. Moreover, Nelly is privileged to the sympathy of the gentry which is not the case with Joseph who is perceived as a rude person. Nelly fills 'an in-between space understanding perfectly dialect, but speaking educated English' (Fegan, 2008, p. 15). That is why she narrates accurately the conversations of Joseph and the other characters from the upper class as well.

Fernandez comments on Nelly and other Victorian servants' language: 'they mimic the culture of the middle class, especially through their claim to literacy and familiarity, sober industrious and dedicated, Nelly Dean epitomizes the phenomena of respectability' (Fernandez, 2009, p. 54). Fernandez continues to claim that this type of servants 'forgo the power of the pen to offer oral histories that flaunt their apparent godliness discipline and commitment to social and civic order' (Fernandez, 2009, p. 56). Nelly's position as a servant does not prevent her from being literate and does not deprive her of respect. She occupies a very important space in the story as the main narrator of many events.

Therefore, she breaks down the anticipations of Lockwood who intends that her narration would be 'regular gossip'. He asserts that her language is as refined as his own and different from that of Joseph. Her literacy and power of narration upset his previous perception of how the servant behaves and speaks. She threatens Lockwood's position as the primary narrator of Wuthering Height, which Fernandez points out as: 'Servant logic resists bourgeois norms' (Fernandez, 2009, p. 18). Ultimately, her literacy stands for the mutability and the agitation of the social characteristics which are known in the Victorian era.

In brief, social mobility is represented through the language change of characters Hareton, Heathcliff, Catherine, and Nelly who tend to accommodate their linguistic behaviour to fit another social class and to acquire respectability. They endeavour to class themselves off, either to please or 
to assert their position as masters and upper-class people. Stewart relates this social mobility to rather a higher sense and comments:

Reading is quite literally the end of the curse for Hareton. Hareton is in fact the fourth servant freed to mastery by reading, for in addition to Joseph's obsessive relation to the Scriptures, and Heathcliff's ascendance after his return from educating himself, Nelly has read or looked at every book in the library at Thrushcross Grange - even the Greek, Latin, and French books she knows (Steward, 2004, p. 189).

Meanwhile, Catherine wants to show that she is a lady of the gentry and asserts her position as a refined woman; Heathcliff tries to align himself in a new social class and wants to exercise his power as the owner and, therefore, a master. Hareton is rehabilitated by Cathy and finally assimilated as a member of the gentility by the end of the story. As far as Nelly is concerned, she longs for respect and socialization.

Nevertheless, Joseph represents social immobility; he resists all the conditions and retains his power by his local speech and his judgemental stances of his social environment. The only relation he has with literacy is that with religious books. Nelly informs us that he: 'ransacks the Bible to rake the promises for himself and flings the curses at his neighbor'. He also obliged Catherine and Heathcliff to read them but in vain thus, he perceives them as uncivilized and unreligious. Eventually, Joseph's resistance to the harsh climate and the weather of the moors are epitomized through maintaining his language and social position to the end of the story. He keeps speaking dialect without looking to learn or seriously imitate Standard English to achieve successful communication with other people.

\section{Conclusion}

Through language, Bronte aspires to instruct, forward moralities, and religious thoughts. She shows the religious stance of the character Joseph who is viewed by Feather-Waddington as a religious hypocrite and self-righteous by Nelly. His religious perception reflects the common views of the population of the Yorkshire area which the writer tries to convey. E. Bronte endeavours to enlighten her reader about the religious and social conventions of this remote area in which religion impacts individuals. Joseph is portrayed as a religious, rude, and unintelligible figure who perceives himself as a minister of God trying to save others from hell and destruction yet; his vision is misleading. The mastery of the dialect and Standard English shows that the writer displays the social and the cultural properties of her characters through their linguistic performance. At the same time, she creates a diglossic situation when shifting between the two varieties of English through which she communicates different stances and speech habits.

Although conventional literature believes that only protagonists and the principal characters' speech can be rendered in Standard English to keep a clear distinction between heroes and minor characters, Joseph and Nelly's linguistic performance puts him at the centre of the novel's fictional lines. Their significance cannot be neglected, since there are only a handful of scenes in which they do not show or do not deserve mention. They place the novel in its locality, tradition, idiom, and ideals. Joseph is not a 'minor' character, placed somewhere 'behind' the gentility. He is the rough base of the novel's purity. He has continually been there until the end. Nelly too, is placed at the centre of the story showing her distinct role as a narrator who clearly and faithfully reports the events in dialect and Standard English

\section{References}

Bronte, E. (1849). Wuthering Heights (2010 ed.). London, UK: Harper Press.

Chapman, R. (2017). Forms of speech in victorian fiction. London, UK: Routledge.

Fegan, M. (2008). Wuthering Heights: character studies. London, UK: Continuum. 
Ferguson, S. L. (1998). Drawing fictional lines: dialect and narrative in the victorian novel. Race, Gender, Religion, and Other Dangerous Things, 32(1), 1-17.

Fernandez, J. (2009). 3 oral pleasures: repression and desire in emily Bronte's Wuthering Heights (1847) and Elizabeth Gaskell's The Old Nurse's Story (1852). In J. Fernandez (Ed.), Victorian servants, class, and the politics of literacy (pp. 65-98). Abingdon, UK: Routledge.

Gorlach, M. (1999). English in nineteenth-century England: an introduction. New York, NY: Cambridge University Press.

Haugen, E. (1966). Dialect, language, nation. American Anthropologist, 68, 922-35.

Hodson, J. (2016). Talking like a servant: what nineteenth century novels can tell us about the social history of the language. The Gryeter Journal of Historical Sociolinguistics, 02(01), 27-46. doi:10.1515/jhsl-20161002

Petyt, K. M. (1985). Dialect and accent in industrial West Yorkshire. Amsterdam, Netherlands: John Benjamins.

Solano-Flores, G. (2006). Language, dialect, and register: sociolinguistics and the estimation of measurement error in the testing of English language learners. Teachers College Record, 108(11), 2354-2379.

Steward, S. (2004). The ballad in Wuthering Heights. Representations, 86(01), 75-97. doi:10.1525/rep.2004.86.1.175

Stuchiner, J. (2013). The servant speaks: Joseph's version of Wuthering Heights. ANQ: A Quarterly Journal of Short Articles, Notes and Reviews, 26, 191-196. doi:10.1080/0895769X.2013.805111

Waddington-Feather, J. (2003). Yorkshire dialect. Shrewsbury, UK: Feather Books.

Wardhaugh, R. (2002). An introduction to sociolinguistics (4th ed.). Maiden, MA: Blackwell. 